\title{
Acquiring Land In Tribal Areas
}

\author{
Kahkashan Kamaal \\ Centre For The Study Of Law And Governance, Jawaharlal Nehru University
}

\begin{abstract}
This Piece On The Whole By Making A Case Study Brings A Focus On Alienation Of Tribal Land Rights In India By The Process Of Land Acquisition Under The Power Of 'Eminent Domain' Of The State. It Discusses Various Acts Of Land Acquisition From 1894 To The Recent Act Of 2013 Also Known As Right To Fair Compensation And Transparency In Land Acquisition, Rehabilitation And Resettlement Act, 2013. The Case Study Has Highlighted The Atmosphere Of Legal Pluralism Making It A Topic Of Extensive Research. Also It Has Focused On Tribals Right To Property Vis A Vis State's Land Acquisition Acts. Especially For The Tribals, Land Is More Than A Commodity But Due To Marketization And Commercialization, Land Has Ceased To Be An Identity And Has Become More Of A Commodity. State's Repressive And Arbitrary Acts And Laws Have Led To The Displacement Of Tribals And Thus Making Them More Vulnerable To The Dangers Of Pauperization And Marginalization. The Concluding Remarks Made In This Piece Point Out That The Land Lost Due To Such Acquisitions Become Irreparable For The Tribals Even With The Provisions Of Rehabilitation And Resettlement Packages Because Here Land Is Linked To An Identity Than A Mere Commodity.
\end{abstract}

Key Words: Tribals, Identity, Displacement, Land Acquisition, Eminent Domain

\section{INTRODUCTION}

According To The United Nations' Estimation There Are Nearly 300 Million Indigenous People In The World And India Itself Accounts For 70 Million Populations Of Indigenous People Alone. Therefore It Is More Than 8 Percent Of The Total Population (Gilbert, 2005). These Indigenous People In India Can Be Found Living In Starting From Northern Mountains To The Central And Southern Part Of The Country Which Represents A Complex And Rich Diversity Of India And The World. However, Numerically They Represent High And Low Density In Different Parts Of India, Like They Are Highly Concentrated In The Central And North Eastern States Than The Other Parts Of The Country. The Government's Position In Regard To Its Indigenous Population Has Shown Double Standards. On The One Hand, The Constitution Of India Recognizes The Rights Of These Indigenous Population And Guarantees A Positive Discrimination System Against Them But On The Other Hand The Policies Of The Government Have Always Been On The Side Of Oppression And Appropriation Of Indigenous Land And Resources. Thus, The Legal Framework Gets Defeated In Protecting The Rights Of The Tribals By The Poor Implementation And Ill Equipped Policies Of The Government (Ibid). The Reason For Tribals' Struggle Is Chiefly The Land Ownership Issue. Tribals All Over The Country Are Almost Facing Similar Problem Of Self Autonomy, Restoration Of Their Ancestral Lands And Recognition Of Customary Land Tenure Systems. The Forefront Land Struggle Can Be Seen From North Eastern States To Southern States. The Struggle For Self Determination Is The Central Feature Of The Struggles In The Northeastern States And Struggles For Access To Natural Resources And Right To Livelihood Through Legal Ownership Of Land Or The Right To Live On Their Own Land In Other Parts. But These Struggles Get Suppressed By The State, Leading To The Extensive Human Rights Violation (Ibid). Though, Tribals Rights On Their Land Is Guaranteed By The Constitution With Specific Legislations But The Violation Of These Rights And Poor Implementation Of These Legislations Have Led The Struggles For The Claim Over Their Land, Self Recognition And Autonomy, Acute.

\section{DEFINITION}

The Word Adivasi (Tribal) Is A Conjunction Of Two Words: Adi And Vasi. 'Adi' Means 'Original' And 'Vasi' Means 'Inhabitant' But This Claim Is Not Fully Accepted By The Government Of India As It Confirms That There Are No Adivasis But Only Scheduled Tribes In India. The Argument Which Is Made Against This Backdrop Is That India Is Essentially Hindustan, The Place Of Hindus Who Are Considered As The Original Settlers And Indigenous Population Of India. Therefore Considering A Very Sensitive Issue, The Power To Designate A Population As A Tribal Population Is Given To The President. The President Of The India Has The Power To Confer The Designation Of 'Scheduled Tribe' To A Certain Population Under A Decree Issued By Him While Granting Them With Special Protection Defined In The Constitution Of India. 
The Constitution Itself Thus Defines 'Scheduled Tribes' In Article 366 (25): 'Scheduled Tribes' Means Such Tribes Or Tribal Communities Or Parts Of Or Groups Within Such Tribes Or Tribal Communities As Are Deemed Under Article 342 To Be Scheduled Tribes For The Purposes Of This Constitution.' At The International Level India Rejects The Recognition Of Tribals As The Indigenous People. Indian Government Argues That Definition Of Indigenous People Does Not Apply Only To The Tribals Rather It Applies To The Whole Population Of India. But It Is Noteworthy That India Is The First Country To Recognize The International Labor Organization Convention 107 Which Concerns With The Indigenous Population. Since There Are Some Positive Provisions In The Constitution Of India Regarding Tribals But Seem Notional Because The Implementation Of These Provisions Lack Political Will (Ibid).

\section{INDIAN POLICY TOWARDS THE TRIBAL POPULATION}

In 1874, British Introduced The Demarcation Of Scheduled Areas Which Continued Even After Independence That Sought For Special Protection Of The Tribals Of India. One Of The Foremost Policies Of The State Was The Protection Of Land Alienation Of The Tribals From The Non Tribals. The Two Annexes Which Deal With The Protection Of Tribal Land Rights Are The Fifth Scheduled And The Sixth Schedule Of The Constitution. The Fifth Schedule Gives Special Protection To The Tribals Who Reside Under The Fifth Scheduled Area Demarcated By The President. The Main Reason Behind Demarcating These Areas As 'Scheduled Area' Is To Give Special Protection To The Tribals From The Alienation And Development Of Their Land (Ibid).

\section{LAND ALIENATION AMONG TRIBALS}

Tribals Have Considered Land As Their Heritage. Leaders Of Tribals Like Tilka Manjhi, Birsa Munda, Siddhu Kanhu And Many Others Have Seen Land As Their Mother And Have Fought Struggles Against The British To Protect It. However, Tribals Have Been Continuously Alienated From Their Land By The People Who Have Seen It Only As A Property. Therefore Jharkhand Serves The Best Example Of Alienation Of Tribal Land By The So Called Civilized Masses. Land Alienation Of Tribals In The Chotanagpur Region Began In The Medieval Period But Reached Its Height In The British Regime. The Permanent Settlement Act Of 1793 Introduced The 'Zamindari System' Leading To The Tribals Upheaval (Dungdung, 2010). As A Result Tribal Upsurge Began Which Led To The Passing Of Protective Land Legislation Of Adivasis In 1908 Called The Choatnagpur Tenancy Act, Wilkinson Rule 1837 And Santhal Pargana Tenancy Act 1949. The Objectives Behind These Legislations Were The Protection Of Tribal Land, Traditional Self Governance And The Preservation Of The Tribal Culture (Ibid). Bihar Area Regulation Act Of 1969 Regularized The Transfer And Sale Of Tribal Land. Also The Special Area Regulation Court Was Established Which Prevented The Sale And Transfers Of Tribal Land To Non Tribal Without The Permission Of The District Collector. But These Regulations Became Useless As Lots Of Tricks Were Being Used To Acquire Tribal Land By The Non Tribals. The Best Trick Was To Marry A Tribal Girl And Register A Tribal Land In Her Name (Ibid). The Second Reason Of Tribals Losing Their Land Was That Loan Borrowed By A Tribal Was Repaid Through Giving Their Land To The Money Lenders. Also Many Illegal Documents Of Land Transfers Through Threat And Coercion Were Used To Acquire The Land Of The Tribals. Dungdung Argues That Empowering The District Collectors To Look After The Land Transfers Has Also Caused A Huge Loss As Most Of The DC's Being Non Tribals Have Always Justified The Illegal Transfers Done By Non Tribals. Another Major Cause Of Land Alienation Of Tribals Is The Amendment In The Protective Laws. For Example, In 1947, Chotanagpur Tenancy Act Was Amended For Industrialization, Urbanization And Infrastructural Development Which In Turn Led To The Huge Loss Of Land Of The Adivasis (Ibid). Thus, These Were The Various Method And Reasons Of Land Alienation Of Tribals Especially In Chotanagpur Region.

\section{DISPLACEMENT LEVEL IN JHARKHAND}

Nearly 80 To 90 Percent Of The Population Gets Displaced Because Of The So Called Development Projects, Dams And Various Other Infrastructure Projects And Merely 25 Percent Of Them Are Somehow Rehabilitated. The Benefits Out Of These Projects Are Used By The State, Urban And Upper Classes, Landlords, Bureaucrats, Contractors, Engineers, Politician, Project Officers And Many Others (Ibid). But The Tribals Who Have Sacrificed Their Land For These Projects Do Not Even Get A Rehabilitation Package, Leave The Benefits Out Of The Projects. Even The Promises Made To These Innocent People Of Compensation And Jobs Are Never Fulfilled. These People Have Been Betrayed Through Fake Promises And Still This Forced Acquisition Is Going On Not Only In Jharkhand But Across The Country. Thus, These Reasons Have Become The Backbone Of The Struggle Of The Tribals Against The State Where Cheating And Betrayal Are Done In The Name Of Development And Therefore They Believe In A Mass Struggle Against The State To Protect Their Land. 


\section{DESTRUCTION OF TRIBAL IDENTITY AND CULTURE}

Tribals Derive Their Cultural Strength From The Natural Resources They Possess. They Represent A Very Unique Culture Which Shows A Close Relationship Between Tribals And The Nature. This Closeness Of The Tribals With Nature Can Be Seen In Their Cultural Ethos And Wall Paintings, Lifestyles, Relationship, Attitudes And Behavior. The Folk Dance, Songs And The Celebration Of Their Festivals Show Their Collective Thought And Community Thinking. Men And Women Enjoy Same Rights And Women Enjoy All The Freedoms Which Men Do. In Fact Relatively The Tribal Women Enjoy More Freedom Than The Women Of Main Stream Society. The Tribal Culture Has Been A Backbone For The Survival Of The Tribals Which Flourishes Around The Nature And Natural Resources. This Culture Of The Tribals Have Been Developed Through Centuries And Is A Community Based Conservative System Which Tries To Preserve And Conserve The Natural Resources Transferred To Them Through Their Ancestors. Therefore The Natural Resources Which Are Inherited By The Tribals Are Used Judiciously And Preserved For Posterity (Ibid). Tribals Who Are The Indigenous People Of India With Unique Culture, Identity And Autonomy Have Been Continuously Been Deprived In Terms Of Development And Have Been Denied Rights And Justice By The State. The Dependence Of The Tribal Community On Natural Resources Is Not Solely Based For Their Livelihood Rather Their Whole Social, Economic, Political And Cultural Life Is Based On Natural Resources Including Their Identity, Autonomy And Customs. They Are Not Only The Consumers Of Natural Resources But The Protectors And Conservators Of These Resources (Ibid).

\section{DISPLACEMENT AND THE LAW}

The Abetment For Displacement For The So Called Development Finds An Expression In The Statute Law Of The Country Where The Cost Of Public Interest Are Paid By The Minorities Of The Society Especially, Economically, Socially And Political Marginal Sections Like The Tribals. The Law And The State Power Are The Driving Force Behind This Huge Mass Displacement. Further, The Law Acknowledges The Displacement Of The Individually Dislocated Person And Henceforth Has No Recognition For The Community Displacement Or Mass Displacement. The Priority To The Development Has Led The Displaced Mass In A Traumatic And Impoverished State. The Cost Which Is Incurred By This Huge Mass Displacement, According To Ramanathan, Is Externalized Through The Cost Benefit Calculation. A Detailed Study Of Law Confirms And Reinforces This Position (Ramanathan, 1996). The Statute Has Its Own Influence On The Profound Understanding Of Judicial Interpretation Of Displacement Problem Which Shows Lack Of Empathy Towards The Displaced Saying That 'Preferential' Treatment Of The Displaced People Will Go Against The Constitutional Mandate Of Equality Promised In The Constitution. Thus, The Statute Laws Not Only Directly Affect The Displacement Of The People But Also Indirectly Push The Law Of Labor, Crime And Illegal Living (Ibid). The LAA Of 1894 Is The Statutory Statement Which Defines State's Power Of Appropriating Land And The Power Of Ultimate Control Over Any Piece Of Land Within Its Territory. It Gives No Cognizance To The Consent Of The Individual Whether He/She Wants To Part Away From The Land Of Which He/She Is The Owner. The Amendment To The Act In 1984 Went Further For The Inclusion Of The Payment Of Compensation Therefore Statutory Responsibility Of The State Ceasing Upon Such Payment. The Displacement Caused By The LAA Without The Provision Of Rehabilitation Was Justified By The State's Power Of Compulsory Acquisition Before The New Act Of 2013 (Ibid). Thus, Displacement Is Neither In The Statement Of Law Nor It Is A Concern Of Law Though Is Inevitable. The Acquisition Being Purpose In Public Interest Makes The Appropriation Conclusive. As We Know, Law Draws Its Legitimacy By The Acceptance Of Public And Popular Support. But The Mass Displacement Through This Statutory Statement Has Led To The Popular Condemnation And Hence Has Cornered The Law Into Rethinking Its Propositions (Ibid).

\section{EMINENT DOMAIN}

To Invoke Further The Public Good Or The Fulfillment Of The Purpose To Make Good For The Greatest Number Of The Society, The State Has The Power Of Eminent Domain. This Power With The State Apparatus Has Empowered The State To Acquire Any Land Within Its Territory, Hence Making Its Use For Public Purposes. To Invoke Further Public Good, This Right Of The State Is Considered Necessary. As A Result The Consent Of The Land Owners For Giving Up Their Land For A Public Purpose Has Been Completely Eroded And Issue Of This Sort Is Entertained. The Only Concession To This Statute Is The Provision Of Compensation Which Causes A Great Legal Injury To The State's Power Of Eminent Domain (Ibid). Permanent, Temporary Or Partial Acquisition Can Be Done Under This Power Which As A Result Surrenders The Right Between The Land Owner And His/Her Land. Once The Right Of The Owner Is Surrendered To The State, Even If There Is Any Change In The Status It Will Have No Effect On The Person Who Has Lost His/Her Land. Illustratively, The Land Acquired To Build Up A Heavy Engineering Corporation In Dhurwa, Ranchi, Made Thousands Of Families Displaced From The Area And Compelled Them To Live In Sheer Destitution With Little Or No Compensation. After The Completion Of The Project Of HEC, The 
Government Found Out That It Has Acquired More Area Than Was Required But It Did Not Return The Land To The Owners And Extra Land Is Left Unused And Barren. Therefore, The Over Appropriation Of Land In Excess To What Is Needed For The Purpose For Which The Land Is Acquired, Cannot Restore The Status Or The Relationship Between The Individual And His/Her Lost Land And Cannot Confer Any Right On The Land To The Displaced Person (Ibid). The Doctrine Of Eminent Domain Ensures The State's Power To Seek Any Land And Resources Within Its Territory And Goes For No Answerability As It Carries The High Ground Of Moral And Pubic Good In Turn Of Acquisition.

\section{THE ROLE OF JUDICIARY}

The Role Of The Judiciary Becomes Important When The Administrative Processes Increase The Inequality Between Those Displaced And Those Who Hold The Power To Displace. The Judicial Process Therefore Comes Into Play In Neutralizing Such Inequality By Considering The Rights Of Those Displaced (Ibid). Specifically In These Sorts Of Cases, Public Interest Litigation Seems To Be More User Friendly And People Friendly As It Makes The Courts Accessible To The People And Fights For The Larger Public Good, Acknowledging The Existence Of Interest Of The Community. The Courts Are Therefore Expected To Provide Reliefs Ranging From Discarding Of The Project, Halting The Project Till The Displaced Are Rehabilitated, To Hold The Project Authorities Of Making False Promises To Gain Acceptability During The Planning Process Or Recognizing The Rights Of The Displaced And Invoking These Rights As A Fundamental Right Which Are Non- Negotiable Either With The Exercise Of Eminent Domain And A Public Purpose Cause Or For Enhancement Within The Law Of Compensation (Ibid). But The Courts Rely On The Law Or What The Statutes Say. Reasoning Of The Court Is Influenced By The Statute. The Law Which Has The Marginal Representation Of The Displaced People's Rights Have Had To Rely On The Policies Which Have No More Than A Persuasive Effect. Courts Are Reluctant To Deal With The Difficulties Of The Policy Implementation. On The Other Hand, These Courts Have A Reiterative Enforcement Of The Power Of The State Pertaining To Acquisition. Thus To Expect A Remedial Policy Or Judgments Out Of The Courts Is An Illusionist Expectation And Expecting A False Hope Out Of The Judiciary. The Indian Judiciary's Role In Interpreting The Law Of Acquisition Particularly The Eminent Domain Power Of The State Has Most Of The Time Favored The State. It Has Held That Power Of The State To Acquire Property In Public Interest Acquires An Inherent Power Therefore It Is Not The Prerogative Of The Court To Canvass The Purpose Of Eminent Domain Unless The Power To Holding Some Particular Land Is Outside The Purview Of The State Power (Dias, 2009).

\section{COMPENSATION}

Compensation Is Seen As The Component Of Justice Used To Reduce The Inherent Justice Of Compulsory Acquisition. To Soften The Blow All The Laws Pertaining To Acquisition Carries A Provision For Compensation. Yet, Its Moral Base Has Been Eroded In The Limited Understanding Of The Concept Of Compensation. It Therefore Is Ill Equipped Where The Notion Of Total Or Just Compensation Is Unknown And Has Failed To Internalize The Misery Led By Displacement. Where The Population Categorizes The Powerlessness And Poverty It Is Very Unlikely That Displaced People Are Able To Use The System To Their Advantage. The Law Does Not Recognize The Coercion Which Plays An Important Role In Acquisition. The Dominant Equation Of Market Value Or The Notional Value In The Market Of The Acquired Land Is The Meaning Of The Compensation And Thus Treats The Displaced Person As A Willing Seller. Compensation In Terms Of Land For Land Finds A Mere Expression In The Statute But Has No Binding Obligation On The State. The Non Recognition Of Mass Displacement In The Statute Has Also Led To The Non Sensitivity Of Compensation Towards Them As It Recognizes Only The Individual Rights. The Law Of Compensation Does Not Inhabit The Trauma Involved In Displacement, Fragmentation Of Communities, The Breakdown Of Support Structures, Poverty Of The Displaced, Increased Susceptibility Of Exploitation Of The Protected Population Where They Have Been Dislocated, Indulgence Of The Displaced In The Illegal Activities Out Of Impoverishment Etc. (Ramanathan, 1996). Thus, It Can Be Said That Computing The Cost Of Compensation, The Presumption Of Public Purpose, The Implication Of Eminent Domain And The Power Of Acquisition Have All Led To The Issue Of Mass Displacement Which Is A No Issue For The State.

\section{RIGHTS OF THE MARGINALIZED AND MINORITIES}

As Already Noted In The Above Paragraph, Displacement Predominantly Affects Those Who Are Politically, Economically Socially And Geographically Poor. When Development Induced Displacement Occurs It Shows The True Picture Of The Disruption Of Lives Of Those Displaced And The Contrasting Picture Of Power Of An Elite Minority Where There Is No Place For Poor Majority In The Developmental Model (Velath, 2009). It Is The Tribal People Of India Who Bear The Burden Of Disproportionate Development. These Tribals Are Very Much Dependent On Their Private Land As Well As Common Property Resources Where Common Property Resources Are Recognized As State Property And The Absence Of Any Legal Formal Title Of The 
Landless And People Dependent On The Common Property Have No Right To Compensation (Fernandes, 2001). Thus Development Induced Displacement Leads To Large Scale Of Human Rights Abuse.

\section{EROSION OF THE TRIBAL LAND RIGHTS}

Property Rights Have Become The Natural Gathering Force For Modern Tribal People's Movement Around The Globe And Therefore Nations Have The Duty To Recognize The Proprietorship Of These Tribal Communities Over Their Natural Resources As Principle Of 'Human Justice. Yet The Tribals In India Have Been Continuously Deprived Of Their Property Predicated On The Thresholds Of Recommendations And Consultations (Kurup, 2009). Some States Have Individually Sought To Protect The Tribals Of Their State With Their Separate Legislations And Law Pertaining To The Protection Of The Tribal Land And Natural Resources Which Prohibit The Private Purchase Of Tribal Land By The Non Tribal But There Is No Legislation Which Prohibit The State's Right To Acquire The Land Of The Tribals In The Name Of 'Public Interest'. In Fact These Acquisitions Are Moreover Backed By The Appropriation Legislation Of Land Acquisition Act Which Justifies The Taking Of Private Property For Public Use And These Appropriations Are Exercised Through The 'Authority Of Law'. Section 4 (I) Of The PESA Authorizes The Expropriation Of Tribal Land In The Scheduled Area, Explicitly Through The Establishment Of 'Authority Of Law'. This In Turn Makes The Tribal Unable To Prove That The Acquisition Henceforth Made By The State Is Illegal Without Having Proper Consultation. Thus, Even Though Some Property Rights Are Being Given By The States To The Tribals For The Protection Of Their Land, Like Chotanagpur Tenancy Act, Santhal Pargana Tenancy Act, PESA Etc. Have Failed To Protect The Tribal Land From Forced Acquisition By The State.

\section{NAGRI (JHARKHAND) AS A CASE STUDY}

As Per 2011 Census, India's Scheduled Tribe Population Accounts For 8.6\% Of The Total Population. The Two Main Regions Of Their Settlement Are The North Eastern Region And The Other Is The Highlands And Plains Of India, Divided Into Fifth And Sixth Scheduled Areas. The Fifth Scheduled Areas Are Andhra Pradesh, Jharkhand, Chattisgarh, Himachal Pradesh, Madhya Pradesh, Gujarat, Maharashtra, Orissa And Rajasthan. Here, The Focus Is On The Fifth Scheduled Areas Of India Particularly Jharkhand, Its Tribal Population And Alienation Of Their Land And Resources.

Nagri, A Tribal Dominated Village With A Population Of More Than 600 Families, Comes In The Ranchi District, Capital Of Jharkhand And Is Declared As A Fifth Scheduled Area. The Area Is A Fifth Scheduled Area With The Provisions Of PESA And Other Such Laws Pertaining For The Protection Of Tribals Land. This Therefore Becomes The Objective Of The Research To Find Out Whether These Local Laws Are In Operation Or Have They Become Flawed And Inoperative? As For The Past Few Years, Considerable Attention Has Been Given To This Area Where Tribal Land Alienation Has Become One Of The Most Important Issues. Tribals In General Are Facing Continued Land And Resources Alienation By The State Or By The Non Tribal Entities (Sharan, Singh \& Batra, 1999). Large Numbers Of Scholarly Writings Have Extensively Written On The Tribal Land Alienation And Gathered Lot Of Attention Towards The Plight Of The Tribals And Also Suggested Several Amendments To CNTA, SPTA And Other Protective Measures Meant For The Protection Of The Tribal Land. Tribal Rights Therefore Offer A Contesting Site Through Which It Is Interesting To Explore How The Developmental Agenda Of The State Are Responsible For Denying These Very Rights Of Land And Resources To The Tribals (Menon, 2007). Vandergeest And Peluso Have Highlighted The Fact That "All Modern States Divide Their Territories Into Complex And Overlapping Political And Economic Zones, Rearrange People And Resources Within These Units And Creates Regulations Delineating How And By Whom These Zones Can Be Used" (Vandergeest \& Peluso, 1995). This Process In India Has Therefore Led To The Usurpation Of Land And Resources Of The Tribals. The Colonial Act Of 1894 Also Known As Land Acquisition Act And Subsequent Acts Of Land Acquisition Have Empowered The State To Use Its Ultimate Power Of Eminent Domain Superseding The Local Acts And Laws Of Tribal Land Protection. Thus The Overall Scenario Upholds That The Protective Legislations In Jharkhand Have Not Been Upheld And Have Been Subverted By The Appropriation Acts Of The State.

This In Turn Becomes One Of The Very Sensitive And Complex Issues In Jharkhand Which Needs Urgent Attention Of Academicians And Policy Makers So That This Issue Could Be Tackled And More Alienation Of Tribal Land Could Be Stopped Forthwith. This Continuous Alienation Has Not Only Intensified Their Poverty But Has Made These People Foreign In Their Own Homeland (Sharan, 2005). The Theme Of This Piece Focuses Mainly On The Institutional Alienation Which Ostensibly Is For The 'Public Purpose' Where Definition Of Public Purpose Is The Domain Of The Executive. This Institutional Alienation For The Public Purpose And The Issue Of Rehabilitation And Resettlement Has Led To The Mass Agitation Of The Adivasis Of Jharkhand And Other Parts Of The Country. Also There Are Cases Which Come Under The Acquisition Of More Lands Than Required. After The Formation Of Jharkhand These Existential Realities Of Land Acquisition Have Been Added By The Other Current Issues. In This Case The Most Critical 
Challenge Is How To 'Arrest The Process Of Alienation' Of Land And Land Rights Of The Tribals (Ibid). The Current Situation Of Nagri In Particular And Jharkhand In General Is Very Much Complex. On The One Hand The Alienation Of Tribal Land By The Non Tribals Has Declined Because Of The Stringent Local Laws And Acts Which Are Being Implemented In A Very Strict Sense And Also Because Of The Struggles, Movements And Consciousness For The Tribal Land Rights But On The Other Hand State Land Acquisition Is On Rise For The Cause Of 'Public Purpose' (Ibid). Therefore, To Understand This Problem With A Focus On Ground Reality Will Help In Developing A More Sound Understanding Of The Problems Lying In Tribal Areas.

The Basic Premise Here Is The Inherent Contradiction With The Constitutional Provisions, State Policies, Local Laws And Practices In Regard To The Rights Of The Tribals Over Their Natural Resources Which Have Left Them Marginalized, Helpless And Poor. According To Hobbes, In Order To Get Security Of Their Life And Property, Men (People) Surrendered Some Of Their Natural Rights To The State And The State In Turn Has Been Acquiring More And More Property Of Men In The Name Of Governance And Development Which Has Led To The Curtailment Of The Basic Rights Of Men (Samal, 2013) In This Process, When The State Gains Disproportionate Power, The Repercussions Are Particularly Suffered By The Tribal Living In And Around Forests And Hills As They Were And Are Still The Weaker Sections Of The Society. The Expansion Of State Over The Natural Resources And Forests Has Led To The Curtailment Of The Rights Of Tribals Over Their Natural Resources. Now This Has Created A Big Hiatus Between The Fundamental Law Of The Land And Its Objectives And Aspirations With The Natural Resources Of Its Territory And Their Practices Through The Governmental Machinery Which Has Been Very Insensitive Towards The Plight And Marginalization Of Tribals. This Piece Looks Upon The Trumping Of State Laws Over Local Laws Which Were Supposed To Protect The Land Of The Tribals But Have Led Them To Their Increased Marginalization And Pauperization.

\section{CONCLUSION}

Land Alienation Is Such An Issue Which Is Plaguing The Tribals Rights From Almost The Last Two Centuries And Has Aggravated The Plight Of These People Even More. The Case Study Has Revealed The Fact That Alienation Of Land Through The Non Tribals Has Declined But On The Contrary Has Been Arisen By The State Through The Land Acquisition Act Which Entails The Power Of Eminent Domain. It Also Gives A Clear Picture Of The Trumping Of LAA Over The Other Local Laws Like CNTA And SPTA. The Empirical Evidence Shows That Though Being The Protective Land Legislations, They Are Worthless When It Comes To The Acquisition Of Land By The State. The Role Of Gram Sabha Needs To Be Effective In Deciding The Urgency And Public Purpose Issue Before The Alienation By The State.

I Therefore Argue That When Land Acquired Is Linked To Identity, The Appropriation Is Far More Complicated And Complex In The Current System Even With The Terms Of Compensation And Rehabilitation Packages. This Sort Of Acquisition And Expropriation By The State Needs An Attention As It Has Led To The Resistance Movements By These Tribals. The Laws Hence Need To Be Revised And Try To Fit Well With The Tribal Aspirations. Once The Link Between Property And Identity Is Established It Leads To The Immense Magnitude Of The Struggle For Resistance Cannot Be Seen As A Shock. Despite The Reconstitution Of Eminent Domain And The Established And Recognized Identity Of The Tribals, The Regime Is Inherited With The Colonial Legacy And Is Ill Wedded In Its Sources Of Legitimacy. It Has To Be Admitted That The Laws Thus Made By The Constituent Assembly Bears The Legitimacy From The Colonial Authorities And Rather Than Empowering The People Of The Marginalized Society, It Works For The Power Enhancement Of Those Already In Power. This Power Rhetorically Emanates From The Very Concept Of The Commodification Of Land. Development In India Would Have Been Relatively Easy If There Would Have No Bonds Between The Group Of People And The Land, The State Then Would Just Have To Rehabilitate People From One Particular Location To Another. It Would Have Been Just The Question Of Compensation And Rehabilitation Rather Than A Battle For Livelihood, Identity, Culture And Memory Which Has Engulfed The Country In Myriad From Quite A Few Decades. This Piece Highlights The Exploitative Use Of The Institutions And The Laws Of Colonial Legacy Which Have Become Outdated And Ill Fitted Within The Current System And Hence Argue For The Well Suited Design So As To Escape The Resistance Of The People And Fulfill State's Public Purpose Agenda For The Development. Once The State Recognizes And Acknowledges The Attachment And Reliance Of The Tribals To Their Land Which Definitely Go Beyond The Market Value, It Will Establish The Space To Acknowledge That Property Is Very Much Intertwined With Identity Than Is Generally Recognized In The LAA Or The Other Laws Of Property Rights.

\section{REFERENCES}

[1] Dias, Anthony. "Eminent Domain: Displacement And Impoverishment." Beyond Relocation (2009): 183198.

[2] Dungdung, Gladson. "Adivasis Towards Violence." Social Action 60.3 (2010): 25-262. 
[3] Fernandes, Walter. "Conflict In North-East: A Historical Perspective." Economic And Political Weekly (1999): 3579-3582.

[4] Fernandes, Walter, And Niraj Naik. "Development-Induced Displacement In Goa 1965-1995: A Study On Its Extent And Nature." New Delhi. Indian Social Institute (2001).

[5] Gilbert, Jérémie. "India: The Blur Of A Distinction: Adivasis Experience With Land Rights, Self-Rule And Autonomy." (2005): 269-292.

[6] Kurup, Apoorv. "Tribal Law In India: How Decentralized Administration Is Extinguishing Tribal Rights And Why Autonomous Tribal Governments Are Better."Indigenous LJ 7 (2008): 87.

[7] Menon, Ajit. "Engaging With The Law On Adivasi Rights." Economic And Political Weekly (2007): 2239-2242.

[8] Parasuraman, S. "Development, Displacement And Resettlement In India: An Overview." The Development Dilemma. Palgrave Macmillan UK, 1999. 35-56.

[9] Ramanathan, Usha. "Displacement And The Law." Economic And Political Weekly (1996): 1486-1491.

[10] Samal, Avinash. "Institutional Reforms For Decentralized Governance And The Politics Of Control And Management Of Local Natural Resources: A Study In The Scheduled Areas Of India." Politics Of The Commons: Articulating Development And Strengthening Local Practices. Chiang Mai, Thailand (2003).

[11] Sharan, Ramesh, Amar Kumar Singh, And S. X. Batra. "Land Alienation Of Tribals In The Jharkhand Region Of Bihar: Process And Pattern." Social Change 29.3-4 (1999): 146-170.

[12] Samal, Avinash. "Institutional Reforms For Decentralized Governance And The Politics Of Control And Management Of Local Natural Resources: A Study In The Scheduled Areas Of India." Politics Of The Commons: Articulating Development And Strengthening Local Practices. Chiang Mai, Thailand (2003).

[13] Vandergeest, Peter, And Nancy Lee Peluso. "Territorialization And State Power In Thailand." Theory And Society 24.3 (1995): 385-426.

[14] Velath, Priyanka M. "Development And Displacement: Rights Based Theoretical Analysis." Beyond Relocation. New Delhi: Sage (2009): 63-82. 